\title{
Pacific Northwest Condiment Yellow Mustard (Sinapis alba L.) Grower Guide
}

2000-2002

J. Brown, J.B. Davis, and A. Esser

University of Idaho

Moscow, Idaho

Subcontract Report NREL/SR-510-36307

July 2005

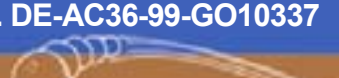




\section{Pacific Northwest Condiment Yellow Mustard (Sinapis alba L.) Grower Guide}

2000-2002

J. Brown, J.B. Davis, and A. Esser

University of Idaho

Moscow, Idaho

NREL Technical Monitor: K. Shaine Tyson

Prepared under Subcontract No. XC0-9-29095-01

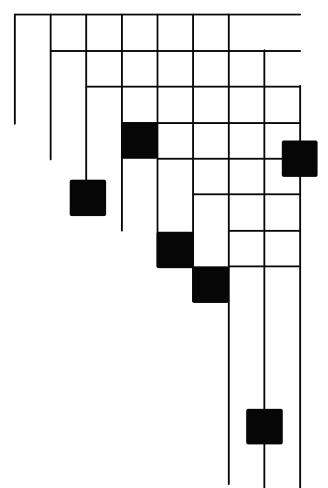




\section{NOTICE}

This report was prepared as an account of work sponsored by an agency of the United States government. Neither the United States government nor any agency thereof, nor any of their employees, makes any warranty, express or implied, or assumes any legal liability or responsibility for the accuracy, completeness, or usefulness of any information, apparatus, product, or process disclosed, or represents that its use would not infringe privately owned rights. Reference herein to any specific commercial product, process, or service by trade name, trademark, manufacturer, or otherwise does not necessarily constitute or imply its endorsement, recommendation, or favoring by the United States government or any agency thereof. The views and opinions of authors expressed herein do not necessarily state or reflect those of the United States government or any agency thereof.

Available electronically at http://www.osti.gov/bridge

Available for a processing fee to U.S. Department of Energy and its contractors, in paper, from:

U.S. Department of Energy

Office of Scientific and Technical Information

P.O. Box 62

Oak Ridge, TN 37831-0062

phone: 865.576 .8401

fax: 865.576 .5728

email: mailto:reports@adonis.osti.gov

Available for sale to the public, in paper, from:

U.S. Department of Commerce

National Technical Information Service

5285 Port Royal Road

Springfield, VA 22161

phone: 800.553 .6847

fax: 703.605.6900

email: orders@ntis.fedworld.gov

online ordering: http://www.ntis.gov/ordering.htm

This publication received minimal editorial review at NREL 


\title{
Pacific Northwest Condiment Yellow Mustard (Sinapis alba L.) Grower Guide
}

\author{
Jack Brown', Jim B. Davis and Aaron Esser \\ Plant, Soil and Entomological Sciences, \\ University of Idaho, Moscow, ID 83844-2339 \\ 1jbrown@uidaho.edu
}

\section{Introduction}

Yellow mustard (Sinapis alba L.), synonymous with white mustard, is a spring annual crop and well adapted to hot, dry growing conditions. It has shown potential as an alternative crop in rotations with small grain cereals and has fewer limitations compared to other traditional alternative crops. Yellow mustard has superior heat and drought tolerance compared to rapeseed or canola (B. napus or B. rapa). It has $55 \%$ higher seed yield than spring canola in regions of the Pacific Northwest (PNW) which receive less than 12 inches of annual precipitation, and also has higher yield than spring canola in areas that receive more than 12 inches of annual rainfall.

Yellow mustard has been grown mainly in Europe (England, France, Germany and Sweden) as a condiment spice for hundreds of years. Earliest document domestication was by the Romans over 2,000 years ago. Yellow mustard is a wind-pollinated species with a strong sporophytic self-incompatibility system. Plants have bright-colored yellow flowers with four nectaries and more branches than most other Brassica species. Yellow mustard is a relative of canola/rapeseed (Brassica napus L.) and oriental mustard (B. juncea L.), but will not cross-pollinate with these crop relatives under field conditions. Yellow mustard can therefore be grown in close proximity to canola, although growers must ensure that the harvested seeds do not get mixed in combine harvesters or grain bins.

\section{Field selection}

The most important decision when growing yellow mustard relates to field selection. Yellow mustard is highly competitive with weed species. In crop/weed competition studies it has been shown that one wild oat plant was as competitive as four canola plants whereas one yellow mustard plant was more competitive than two wild oat plants. Many PNW growers have produced yellow mustard crops without herbicides.

Yellow mustard crop quality is highly affected by contamination with catchweed bedstraw (Galium aperine L.). Catchweed bedstraw infects the crop late in the season and, although there is little damage to crop yield, the catchweed bedstraw seeds have the same size and density of yellow mustard seeds, and separating catchweed bedstraw seeds from yellow mustard seed is very difficult and too expensive to consider on a large-scale. 
Infestation with catchweed bedstraw significantly reduces yellow mustard seed quality, and hence farm price. Therefore choosing fields with no history of catchweed bedstraw infestation is essential.

Perennial weeds like Canada thistle, field bindweed and quackgrass can often be managed by applying a broad-spectrum herbicide (usually Roundup) in the previous fall and again the spring. Grassy weeds can be controlled post emergence using Select ${ }^{\circledR}$ herbicide.

Yellow mustard is highly sensitive to residues of imazamox (Pursuit ${ }^{\circledR}$ ) herbicides that are commonly applied to legume crops in the PNW. Yellow mustard should not be planted in fields where Pursuit had been applied within the previous 60 months. Growers are strongly recommended to check plant-back recommendation on all previously used herbicides before planting yellow mustard.

\section{Cultivar Choice \& Product Quality}

Most yellow mustard cultivars have been developed in Europe or Canada and the only cultivar developed in the US is 'IdaGold'. Other cultivars available in the US are 'AC Pennant', and 'Viscount' released in Canada and 'Tilney' developed in England. Yield differences between available cultivars have tended to be small compared to variation that exists from site-to-site and year-to-year (Table 1). In the Pacific Northwest Mustard Variety Trials 1999-2002 the four cultivars were not significantly different with respect to seed yield. Further details can be obtained from the web site www.ag.uidaho.edu/brassica/.

Table 1. Yield potential of different yellow mustard cultivars grown in the PNW mustard Variety Trials 1999 to 2003.

\begin{tabular}{|c|c|c|c|c|c|}
\hline \multirow[t]{2}{*}{ Cultivar } & Average & 2002 & 2001 & 2000 & 1999 \\
\hline & \multicolumn{5}{|c|}{---------------------------------- lb/acre ---------------------------- } \\
\hline IdaGold & 1456 & 1397 & 1482 & 1406 & 1538 \\
\hline AC Pennant & 1455 & 1277 & 1522 & 1449 & 1571 \\
\hline Tilney & 1418 & 1280 & 1503 & 1422 & 1467 \\
\hline Vicount & 1347 & 1317 & 1415 & 1309 & - \\
\hline Average & 1419 & 1318 & 1481 & 1397 & 1525 \\
\hline LSD 5\% & n.s. & n.s. & n.s. & n.s. & n.s. \\
\hline
\end{tabular}

The primary influence on yellow mustard seed yield in the PNW is rainfall. In general terms yellow mustard can be grown in the PNW regions with over eight inches of rainfall. Expected average seed yield can be estimated by multiplying the annual rainfall by $95 \mathrm{lb} / \mathrm{acre}$, up to 18 inches of rainfall. For example, with an average rainfall of 12 inches, a grower should average 12 × $95=1140 \mathrm{lb} / \mathrm{acre}$. However, seed yield can be influenced by many other agronomic factors (see below). 
Yellow mustard cultivars have different quality characteristics. The two major quality characteristics of yellow mustard are seed meal glucosinolate content (which indicates mustard pungency) and mucilage content (a measure of viscosity after boiling seeds). The major glucosinolate type in all yellow mustard is 3-hydroxybenzyl glucosinolate (sinalbin), which accounts for over $90 \%$ of total seed meal glucosinolate content. IdaGold has high total seed meal glucosinolate content with the other three cultivars being significantly lower. Mucilage content of IdaGold is similarly higher (better processing quality) than Tilney (the industry standard) that is in turn significantly higher than either AC Pennant or Viscount. Despite large differences in quality between cultivars, premium pricing for quality is very rare.

\section{Seeding Time and Rate}

Yellow mustard is planted using standard small grain drills, either conventional double disc openers or a wide range of direct seed drills and air seeders. In general planting yellow mustard as early in the growing season as possible is always advisable. However, yellow mustard is highly susceptible to frost damage and planting too early can result in crop failure and will require replanting.

A study was carried out at the University of Idaho 1994-1996 where three yellow mustard cultivars; IdaGold, AC Pennant, and Tilney, were planted as early as possible given spring rainfall (ranged from April 20 through May 1, early) and 14 days later (late) at each of two locations (Moscow and Genesee, Idaho) in each of the three years (Table 2). Results from this preliminary study showed that later planting dates resulted in significantly higher plant establishment stands and final plant stands. However, early planting resulted in over $400 \mathrm{lb} /$ acre increase in seed yield, albeit related to a slight tendency for increased lodging. Seeding date had no influence on 1000-seed weight. Overall, seeding should be as early as possible given reasonable chance of avoiding frost damage.

Table 2. Seedling establishment, final plant stand counts, crop lodging, seed yield and 1000-seed weight of yellow mustard planted early and planted late.

\begin{tabular}{|c|c|c|c|c|c|}
\hline \multirow[t]{2}{*}{ Seeding date } & Establishment & Final stand & Lodging & Seed Yield & $\begin{array}{c}1000 \text { seed } \\
\text { weight }\end{array}$ \\
\hline & \multicolumn{2}{|c|}{------- plants/yd ${ }^{2}$------- } & ---- 1 to 9 --- & -- 1b/acre -- & $--\mathrm{g} / 1000--$ \\
\hline Early & 72 & 63 & 4.5 & 2,587 & 4.96 \\
\hline Late & 90 & 75 & 5.5 & 2,188 & 4.86 \\
\hline LSD $5 \%$ & 20.4 & 16.3 & 1.1 & 139 & n.s. \\
\hline
\end{tabular}

Yellow mustard should be planted in moist soil at a seeding depth of 0.5 to 1 inch deep. Under ideal conditions, seed can be planted slightly deeper, although deep seeding can result in delayed seedling emergence and reduced plant stands. Row spacing should be 6 to 8 inches, although yellow mustard is more vigorous than canola and wider row spacing can give acceptable ground cover and can often be more practical under direct-seed conditions. 
The University of Idaho study (above) also examined the effect of seeding rates $(4,8$, and $12 \mathrm{lb} / \mathrm{acre})$. Not surprisingly, increased seeding rates resulted in higher plant stands at establishment and harvest. Significant yield reduction was observed with $4 \mathrm{lb} / \mathrm{acre}$ seeding rate (Table 3). However, the yield was not different with 8 and $12 \mathrm{lb} /$ acre seeding rates. Visual inspection of these, and other trials, suggests that seeding rates should not exceed $10 \mathrm{lb} / \mathrm{acre}$, because higher seeding rates can result in crops with spindly plants that out compete one another, resulting in reduced yield. From all studies and experiences optimal seeding rates would be 7-8 $\mathrm{lb} /$ acre under traditional tillage systems and 8-9 lb/acre under direct seed systems.

Teble 3. Seedling establishment, final plant stand counts, crop lodging, seed yield and 1000-seed weight of yellow mustard seeded at 4, 8, and $12 \mathrm{lb} /$ acre.

\begin{tabular}{|c|c|c|c|c|c|}
\hline \multirow[t]{2}{*}{ Seeding rate } & Establishment & Final stand & Lodging & Seed Yield & $\begin{array}{c}1000 \text { seed } \\
\text { weight }\end{array}$ \\
\hline & \multicolumn{2}{|c|}{------- plants/yd² ------- } & ---- 1 to 9 --- & -- lb/acre -- & $--g / 1000--$ \\
\hline 4 lb/acre & 38 & 36 & 4.2 & 2281 & 4.91 \\
\hline $8 \mathrm{lb} / \mathrm{acre}$ & 83 & 72 & 5.3 & 2402 & 4.89 \\
\hline $12 \mathrm{lb} /$ acre & 123 & 100 & 5.6 & 2469 & 4.93 \\
\hline LSD 5\% & 20.4 & 16.3 & 1.1 & 139 & n.s. \\
\hline
\end{tabular}

\section{Fertilizer Requirements}

Yellow mustard plants have extensive root systems that penetrate deep into the soil profile. In studies in Idaho, more than $50 \%$ of all moisture uptake is from below 5 feet in the soil profile, and hence yellow mustard crops can utilize nitrates that have leached down from other crops.

Nitrogen $(\mathrm{N})$, phosphorus $(\mathrm{P})$, sulfur $(\mathrm{S})$ and boron $(\mathrm{B})$ are the most likely to be limiting nutrients in the Pacific Northwest. Growers are strongly advised to have suitable soil tests carried out before planting to ensure proper nutrient management and optimum seed yields.

Several studies have examined the effects of sulfur and boron deficiencies in yellow mustard and found less of a response compared to spring canola. Yellow mustard will respond to sulfur and boron and growers should ensure that no deficiencies exist. Growers should apply 15-20 lb/acre sulfur to soils containing less than $10 \mathrm{ppm} \mathrm{SO}_{4}-\mathrm{S}$. Phosphorus fertilizer should be banded at a rate of 40 to $60 \mathrm{lb} /$ acre of $\mathrm{P}_{2} \mathrm{O}_{5}$ (equivalent to (18 to $26 \mathrm{lb} /$ acre of $\mathrm{P}$ ) when soils contain less than $4 \mathrm{ppm}$ sodium acetate extracted P. A number of PNW soils are boron deficient and 1 to $2 \mathrm{lb} /$ acre of boron should be applied in cases where soil tests are less than $0.5 \mathrm{ppm}$ B. Applications of higher than $2 \mathrm{lb} / \mathrm{acre}$ of $\mathrm{B}$ can easily result in toxic level. B must be uniformly broadcast before or at seeding and never banded. 
The amounts of available nitrogen applied to a yellow mustard crop will be determined by the yield potential of the crop, which is highly related to potential annual rainfall in the PNW. Optimum nitrogen availability has been estimated from field trials at different rainfall potentials in northern Idaho and eastern Washington (Table 4). Under high rainfall situation $12.8 \mathrm{lb}$ /acre of available $\mathrm{N}$ will be required for each $\mathrm{lb}$ of seed yield expected. Therefore, given a potential of $1,900 \mathrm{lb} /$ acre seed yield on a 20 inch rainfall area will require $19 \times 12.9=243 \mathrm{lb} /$ acre of available N. Similarly, under medium rainfall (14-18 inches annually) each $100 \mathrm{lb}$ of seed harvested will require $11.5 \mathrm{lb} /$ acre of available $\mathrm{N}$, and under low rainfall $100 \mathrm{lb}$ of seed harvested will require $10.5 \mathrm{lb} /$ acre of available $\mathrm{N}$. It should be noted that the above recommendations for $\mathrm{N}$ relate to available $\mathrm{N}$ rather than $\mathrm{N}$ applied, and over application can cause yield reductions.

Table 4. Potential yellow mustard seed yield with differening rainfall and available nitrogen.

\begin{tabular}{|c|c|c|c|c|c|c|c|c|}
\cline { 2 - 8 } & \multicolumn{10}{c|}{ Available Nitrogen } \\
\hline $\begin{array}{c}\text { Rainfall } \\
\text { (inches/year) }\end{array}$ & 85 & 10 & 12 & 14 & 16 & 18 & 20 & 22 \\
\hline $\begin{array}{c}\text { Harvested } \\
\text { yield (lb/acre) }\end{array}$ & 659 & 1,073 & 1,403 & 1,654 & 1,829 & 1,935 & 1,974 & 1,978 \\
\hline
\end{tabular}

\section{Disease and insect control}

Yellow mustard is highly resistant to Sclorotinia stem rot and white mold, and fungicides are rarely necessary. Yellow mustard is resistant to or tolerance to flea beetle (Phyllotrete cruciferae (Goeze)), cabbage seedpod weevil (Ceutorhynchus assimilis Payk), cabbage aphid (Brevicoryne brassicae L.), and diamond back moth (Plutella xylostella L.). Compared to canola crops, yellow mustard shows little visible insect damage and the highest yield from plots without insect control. This crop needs less fungicides, insecticides and herbicides than other Brassica crops when grown in the PNW, resulting in fewer input costs and reducing environmental problems associated with agro-chemical use.

\section{Harvest and storage}

Yellow mustard is highly resistant to seedpod shatter and can be harvested by direct cutting with a combine (i.e. does not require swathing prior to harvest). Harvest should be done when seed moisture content is less than $10 \%$ and seed should not be stored for long periods unless seed moisture content is less than $8 \%$. 


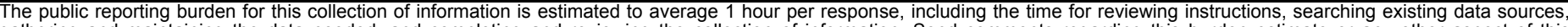

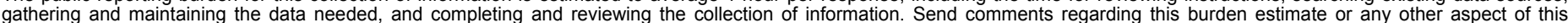

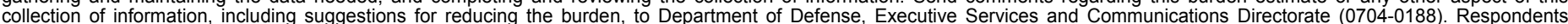

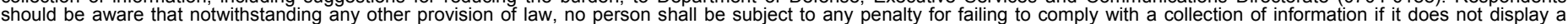

should be aware that notwithstanding

PLEASE DO NOT RETURN YOUR FORM TO THE ABOVE ORGANIZATION.

\section{REPORT DATE (DD-MM-YYYY) July 2005 \\ 2. REPORT TYPE \\ Subcontract Report}

4. TITLE AND SUBTITLE

Pacific Northwest Condiment Yellow Mustard (Sinapis alba L.)

Grower Guide: 2000-2002
3. DATES COVERED (From - To) 2000-2002

5a. CONTRACT NUMBER

DE-AC36-99-G010337

5b. GRANT NUMBER

5c. PROGRAM ELEMENT NUMBER

5d. PROJECT NUMBER

NREL/SR-510-36307

5e. TASK NUMBER

FC059400

5f. WORK UNIT NUMBER
7. PERFORMING ORGANIZATION NAME(S) AND ADDRESS(ES)

University of Idaho

Moscow, Idaho
8. PERFORMING ORGANIZATION REPORT NUMBER

XC0-9-29095-01

9. SPONSORING/MONITORING AGENCY NAME(S) AND ADDRESS(ES)

National Renewable Energy Laboratory

10. SPONSOR/MONITOR'S ACRONYM(S) NREL

1617 Cole Blvd.

Golden, CO 80401-3393

11. SPONSORING/MONITORING AGENCY REPORT NUMBER NREL/SR-510-36307

12. DISTRIBUTION AVAILABILITY STATEMENT

National Technical Information Service

U.S. Department of Commerce

5285 Port Royal Road

Springfield, VA 22161

13. SUPPLEMENTARY NOTES

NREL Technical Monitor: K. Shaine Tyson

14. ABSTRACT (Maximum 200 Words)

This report is a grower guide for yellow mustard. Yellow mustard (Sinapis alba L.), synonymous with white mustard, is a spring annual crop and well adapted to hot, dry growing conditions. It has shown potential as an alternative crop in rotations with small grain cereals and has fewer limitations compared to other traditional alternative crops.

\section{SUBJECT TERMS}

yellow mustard; white mustard; mustard; canola; growing

\begin{tabular}{l}
\hline 16. SECURITY CLASSIFICATION OF: \\
\begin{tabular}{l|l|l|}
\hline a. REPORT & b. ABSTRACT & c. THIS PAGE \\
Unclassified & Unclassified & Unclassified \\
& & \\
\end{tabular} \\
\hline
\end{tabular}

\begin{tabular}{|c|c|}
\hline $\begin{array}{l}\text { 17. LIMITATION } \\
\text { OF ABSTRACT }\end{array}$ & $\begin{array}{l}\text { 18. NUMBER } \\
\text { OF PAGES }\end{array}$ \\
\hline UL & \\
\hline
\end{tabular}

19a. NAME OF RESPONSIBLE PERSON

19b. TELEPHONE NUMBER (Include area code) 